\title{
Non Performing Loans on Regional Development Bank in Indonesia and Factors that Influence
}

\author{
Suryanto \\ Department of Business Administration, Padjadjaran University \\ Email: suryanto70@yahoo.com
}

\section{Doi:10.5901/mjss.2015.v6n4p280}

\begin{abstract}
This study aims to analyze the non-performing loan (NPL) in the Regional Development Bank (BPD) in Indonesia and determine the factors that can influence it. This study uses a quantitative approach. The data used in the form of panel data from the financial statements of Regional Development Bank in Indonesia as many as 26 banks 2009-2013. Factors examined its effect on the NPL is a measure of a bank (SIZE), the capital adequacy ratio (CAR), the level of bank efficiency (BOPO), the loan interest rate (LIR), and liquidity (LDR). Estimation model used is the Random Effects Model (REM) with the analytical technique used is multiple regression. The results showed that the NPL BPD 2:14\% average is still within the tolerance limits set by Bank Indonesia. Variables that significantly affect the NPL is the level of efficiency of banks, mortgage interest rate and liquidity of banks. While the variable size of the bank and Modak adequacy ratio has no significant effect on the level of NPL.
\end{abstract}

Keywords: NPL, Bank Size, CAR, BOPO, LIR, LDR

\section{Introduction}

Economic development of a country depends on the development and the contribution of the banking sector. The banking sector in the modern economic system, described as the heart pumps blood flow in the form of capital to the rest of the economic lifeblood. Thus, the problems arising in the banking sector will affect the national economy. The same thing happens, when the economy stagnated also affected the banking sector. Function as an intermediary bank is not running normally. The banking sector also has a very important role in the recovery process of the country's economy as a whole. This is because in addition to its function as an intermediary institutions, banks also play a role in the implementation of the national payment transactions. Financial intermediation is an important activity in the economy, because it can cause the flow of funds from unproductive to productive parties in managing the fund. Furthermore, it will help stimulate the economy becomes more efficient and dynamic.

Sources of banking funds lent to the public in the form of loans rather than purely funds belonging to the bank itself, but rather is derived from public funds deposited in the bank. The banks try and compete to attract and collect funds from the public in order that they save their money for long periods of time. Public funds are deposited in the bank, generally in the form of savings, deposits, and demand deposits.

Banks not only focus collect funds from customer deposits, funds have been collected is passed back to the community in the form of a loan or credit. This is done so that the collected money in the bank can continue to operate, because the velocity of money through the bank can earn income from interest. The more loans disbursed, the greater the bank's revenue earned. Revenues derived from the difference between bank lending with interest savings.

But not all loans extended by banks free of risk, some of them have a considerable risk and can threaten the health of the bank. One form of credit risk according to the bank's most haunting Dendawijaya (2003) is a non performing loans $(\mathrm{NPL})$, because if there is a lot of non-performing loans will be very detrimental to the bank itself. Although in general, according to Firdaus and Ariyanti (2003) in the banking business almost impossible all outstanding loans will be $100 \%$ run smoothly.

There are several factors that can affect non-performing loans at a bank. Rajiv Ranjan and Sarat Chandra Dhal (2003) conducted a study that the size of the bank have a negative impact on a bank's non-performing loans. The greater the smaller the size of a bank's non performing loan, otherwise the smaller the size of the larger banks non performing loan. The results of different studies conducted by Syeda Zabeen Ahmed (2006), BM Misra and Loaded Dahl (2010), Km.Suli Astrini, I Wayan Suwendra, and I Ketut (2014) that the size of the bank's positive effect on problem loans.

Other researchers are Abhiman Das and Saibal Ghosh (2007) stated that the other factors that can affect the credit 
crunch Capital Adequacy Ratio (CAR). Research results say that CAR negative effect on problem loans. These results reinforced by Zakiyah Dwi Poetry, Yulizar D Sanrego (2011) that the variable CAR responded negatively by NPL. When a bank's CAR rose, the NPL decreased. The results of different studies conducted Vatansever \& Hepsen (2013) that the CAR can be a positive influence on problem loans.

Berger and DeYoung (1997) in his study also said that the NPL is influenced by the efficiency of the banking system. Banks with an efficiency rate lower costs will increase non-performing loans, due to inefficient banks have bad management in managing credit risk and it leads to an increase in non-performing loans or NPL. These results reinforced by Mohd. Zain Abd. Karim, Sok-Gee Chan \& Sallahudin Hassan (2010) and Vatansever \& Hepsen (2013) that the level of bank efficiency negatively affect the credit crunch.

Research conducted and Hermawan Subagyo (2005) and BM Misra Sarat Dahl (2010) shows that there is a positive and significant influence between Loans Interest Rate to NPL. While the results of different studies conducted Aisha and Prasetya (2012) that the loan interest rate has no effect on the NPL.

Another factor that can affect non-performing loans according to BM Misra and Sarat Dahl (2010) is the liquidity of banks. Research results say that LDR significant effect on the NPL. The results of a similar study conducted by Novitayanti and Baskara (2012) that the reduction of the LDR will be responded positively by NPL.

The reasons above indicate inconsistent research findings that affect the NPL. Therefore, further testing is necessary to determine the consistency of the findings when applied to different environmental conditions. This study aims to analyze and find empirical evidence of the influence of Bank Size, CAR, level of efecieny of banks, loan interest rate and liquidity to the possibility of non-performing loans.

\section{Literature Review}

\subsection{Non Performing Loan}

Etymologically, the credit obtained from a term derived in Greek, which credere which means trust. The meaning implies that any lending activities must be based on trust between the creditor and the debtor. A concrete realization in the form of the transfer of funds from the creditor to the debtor for the benefit of certain financing objective has been known to each party.

Understanding credit according to Rachmat Firdaus \& Maya Ariyanti (2011: 2) provision of cash or the equivalent, based on agreements between bank lending and other parties who require the borrower to pay off the debt after a certain period with interest.

Meanwhile, according to Eric L Kohler credit (in True Pudjo Muljono, 2007: 9-10) credit is the ability to execute a purchase or entered into an agreement with a promise of payment will be suspended on an agreed period of time. Another concept presented Mac Leod (in Rachmat Firdaus \& Maya Ariyanti, 2011: 2) that the credit is an individual's reputation, which allows it to obtain money, goods or labor, with the trade them with a promise to pay in a time will come.

Lending by banks should be done carefully, in order to avoid a credit crunch. Nonperforming loans according to Rival (2006) are loans where there is a default in the repayment as per the agreement, so there is no potential loss of arrears or diusaha debtor so that it has the possibility of future risk for banks in a broad sense. Meanwhile, according to Siamat (2004: 174) nonperforming loans can be defined as a loan repayment experiencing difficulties due to the presence of gaps and factors or due to external factors beyond the control of the debtor.

Non-performing loans (NPL) by Riyadi (2006) can be measured by looking at the ratio between non-performing loans to total loans granted by banks. The greater the level of NPL, indicating that the bank is not a professional in the management of credit, as well as providing an indication that the level of risk on bank lending is quite high. The amount of NPL are allowed by Bank Indonesia at this time is a maximum of 5\%. According Taswan (2008) and Bank Indonesia Circular Letter No. 3/30 / DPNP dated December 14, 2001 the calculation of non-performing loans are as follows:

$$
N P L=\frac{\text { Non Performing Loan }}{\text { Total Credit }} \times 100 \%
$$

\subsection{Factors Affecting the NPL}

Given current credit bank can turn into non-performing loans (substandard, doubtful, and loss). To reduce the possibility of a credit crunch, we need to hold ourselves in a systematic introduction of the system in the form of a list of events or symptoms that can lead to credit becomes problematic. The following are some factors that can affect the credit crunch. 


\subsubsection{Bank Size}

The size of a bank can be judged from the total assets of the bank. Banks with large assets possess the possibility to provide large amounts of credit. The greater the asset or assets owned by a bank, the greater the volume of credit that can be extended by the bank. Dendawijaya (2003) argues, the greater the volume of credit provides an opportunity for the bank to reduce the level of spreads, which in turn will lower the level of lending rates (interest rate credit) so that banks will be more competitive in providing services to clients who need credit.

The size of the size of a company according to Rajiv Ranjan and Sarat Chandra Dahl (2003) will affect its ability to bear risks that may arise due to a variety of situations faced by companies associated with its operations.

\subsubsection{Capital Adequacy Ratio (CAR)}

CAR according Dendawijaya (2003) is a ratio that shows how much the entire assets of the bank that contain risks (credit, investments, securities, bills on other banks) participated in finance from the bank's own capital funds in addition to obtaining funds from sources outside banks, such as funds from the public, lending and others. Bank capital should be used to keep the potential risk of loss. CAR according to Siamat (2001). an indicator of the ability of banks to offset a decline in assets as a result of losses banks.

CAR is the capital adequacy ratio, which is one important factor for banks in business development. In accordance with that has been set by Bank Indonesia, the CAR is the capital adequacy which must always be maintained by each bank as a certain proportion of the total Risk Weighted Assets (RWA). According to Firdaus and Ariyanti (2003) RWA shows the value of risky assets that require capital amtisipasi in sufficient quantities.

$$
C A R=\frac{\text { Equity }}{\text { risk-weighted assets }} \times 100 \%
$$

CAR measurements according Kashmir (2012: 273), Dendawijaya (2003) and Hasibuan (2009) which compares capital to risk-weighted assets (RWA). Under the rules set by Bank Indonesia, which refers to the international regulations issued by the Banking for International Settlements (BIS) that for the moment the minimum CAR of banks in Indonesia amounted to $8 \%$ of risk-weighted assets (RWA), or coupled with market risk and risk operational.

\subsubsection{Efficiency levels Bank}

The level of bank efficiency by Siamat (2005) demonstrated the ability of bank management in controlling operating expenses to operating income. According to the bank's operating costs Dendawijaya (2003) are all costs directly related to the business of banks. The cost of the bank's operations consist of interest expense, foreign exchange costs, labor costs, depreciation costs, and others. While operating income by Dendawijaya (2003) is a direct result of the operations of a bank that really has been received. Bank operating income comprises interest income, fees and commissions, foreign exchange income, and other income. The most important thing to achieve operational efficiency is by Koch and MacDonald (2003: 112) is to increase productivity, reduce costs, resulting in maximum output and will affect earnings.

The level of bank efficiency by Dendawijaya (2003), Siamat (2005), (Riyadi, 2006), (Mudjarad, 2012: 518), as well as Kuncoro and Suhardjono (2012) based on a quantitative assessment of bank profitability yangt measured using the ratio of operating expenses to operating income (BOPO). Conceptually, BOPO very large contribution to the banking company's ability to manage its assets to generate earnings. The lower the ratio the better the performance BOPO means the bank's management, because the more efficient use of existing resources in the company. BOPO greater contrast ratio indicates less efficient banks in running their business activities.

According to Bank Indonesia regulation, the ideal value of BOPO ratio is between $50-\% 75 \%$ to demonstrate a good level of bank efficiency. If the ratio is above $90 \%$ and nearly $100 \%$ means that the performance of the bank showed a very low level of efficiency. In accordance with the provisions of the BI, the BOPO ratio of maximum tolerated is $93.52 \%$

\subsubsection{Loan Interest Rate (LIR)}

Banks earn revenue by Hasibuan (2006) from the difference between the interest rate loans to borrowers and the interest that must be given to depositors (cost of funds). Bank earnings will gain bigger if the pricing of credit is greater than the cost of funds. Loan interest rate (LIR) according Kashmir (2010) that the level of interest expense given to the borrower or the price paid by the borrower to the bank's customers. Firdaus and Ariyanti (2003) stated that the determination of lending rates are pricing mechanism of commodities are bought and sold by the bank that the funds or money. 
When determining lending rates by Dendawijaya (2003) should observe and analyze the components of (1) the total cost of funds (2) overhead costs (3) the net margin, and (4) banking tax. According Sutoyo (2000) the higher level of credit risk the higher the interest rate the bank requested. This is because the lender must have additional reserves to cover high-risk credit risk compared to normal credit risk.

\subsubsection{Likuidity Bank}

Liquidity of a bank according to Dendawijaya (2003) demonstrated the ability of banks to meet all withdrawals by depositors, the obligations that have matured, and meet the demand for loans without any delay. While the liquidity of a bank according to Siamat (2005) showed that the bank has sufficient supply of funds to meet obligations.

The size of the bank's liquidity by Dendawijaya (2003) can use the loan to deposit ratio (LDR). LDR is the ratio between the total amount of credit provided the bank with funds received by the bank to measure the ability of bank to repay the withdrawal of funds by depositors by relying loans as a source of liquidity. While Kashmir (2008: 290) explains that the LDR is to measure the composition ratio of the number of loans compared to the amount of funds from the public and their own capital employed. A similar argument by Taswan (2006) that the LDR is the ratio between the volume of loans granted to the funds received or third party funds (Giro, Savings, deposits, and other short-term liabilities).

$$
L D R=\frac{\text { Total Credit }}{\text { Total Deposits }}
$$

The ratio describes the ability of banks to repay depositors withdrawals made by relying on loans as a source of liquidity. Dendawijaya (2003) said that the higher the lower the ability LDR bank liquidity. A high ratio indicates that a bank lends the entire funds (loan-ups) or reatif illiquid (illiquid). Conversely a low ratio indicates that banks with excess capacity liquid funds readily lent (Latumaerissa, 1999)

Bank Indonesia issued a regulation on the amount of standard LDR value according to Bank Indonesia is between $85 \%-100 \%$ (Dendawijaya, 2003). So stock funds raised, can doptimalkan by the bank to carry out activities in lending, where the activity is the most productive asset for the bank.

\section{Methodology}

This study uses a quantitative approach to research the type of verification. Source of data extracted from the financial statements reporting period BPS and Regional Development Bank (BPD) throughout Indonesia. BPD that the unit of analysis, there are 26 banks in the study period from 2009 to 2013. The independent variables in this study, consisting of five variables, namely SIZE (X1), CAR (X2), BOPO (X3), LIR (X4) and LDR (X5 ) as well as the dependent variable, ie NPL (Y).

Data panel is tested with the Hausman test and continued with test assumptions to determine the model Generalize Classical Least Squares (GLS). Hypothesis test is used to test the effect of the independent variable either partially or simultaneously to the dependent variable.

\section{Results and Discussion}

\subsection{Performance of Non-Performing Loans BPD}

NPL performance allowed by Bank Indonesia at this time is a maximum of 5\%. During the period 2009-2013 the average NPL on BPD in Indonesia amounted to $2.14 \%$ with a standard deviation of $1.88 \%$. It shows the performance of BPD is relatively good compared to the maximum limit of the NPL. However, the development of NPL trend shows an increase or negative trend while the other commercial banks in the same period decreased. In Figure 1 shows that the average NPL BPD in 2013 to $2.81 \%$ figure is far enough above the average NPL in 2009 which stood at $1.71 \%$. Negative trend growth in the average NPL BPD starting from the year 2012 as a result because of the BPD are experiencing a very drastic increase in NPL. 


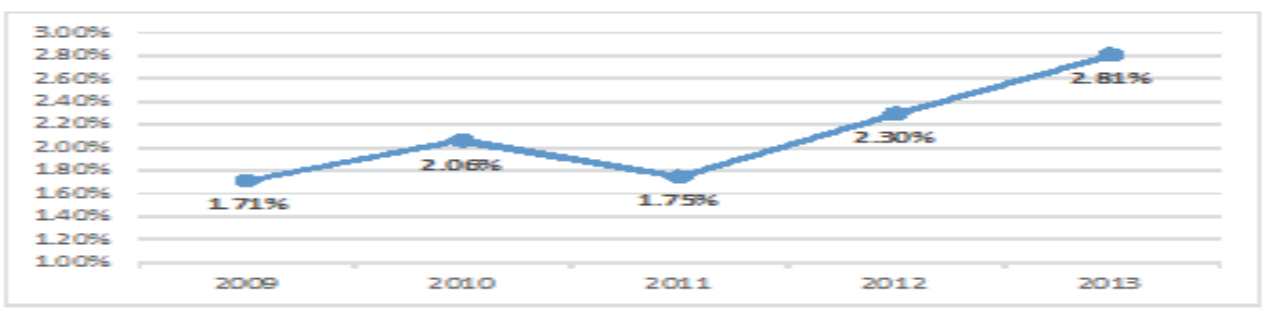

Figure 1. The development of BPD 2009-2013 NPL

Source: Data Processed, 2014

The value of the lowest NPL occurred in 2009 in West Kalimantan BPD 0,09\%. BPD West Kalimantan lending focused on the small and medium enterprises (SMEs) and cooperatives that have a low level of risk. Total lending BPD West Kalimantan in 2009 reached Rp 2.7 trillion, and the majority of flow to the SME and corporate sectors.

While the value of the highest NPL occurred in 2013 in BPD Sumsel Babel NPL of 9.01\%. BPD Sumsel Babel experiencing a trend that is very striking increase in NPL from 2012 to June 2013. This was due to the real sector that experienced the turmoil in 2012 following a drop in commodity prices (rubber and oil palm). Total lending BPD Sumsel Babel in 2013 reached Rp 10.185 trillion, the amount of non-performing loans amounted to Rp 811.007 billion, which includes Rp 525.081 billion substandard loans, Rp 154.856 billion in doubtful loans and bad credit Rp 131.070 billion.

Number of BPD who entered into the category of the BI intensit supervision from 2009 to 2013 decreased, Table 1 shows that in 2013 there are 2 BPD which exceed the tolerance limit risks Bank Indonesia, namely 5 percent. Both the BPD is BPD and BPD Kaltim Sumsel Babel with each level of NPL of $9.01 \%$ and $6.11 \%$.

Table 1. Number of BPD on The Basis Grouping NPL Ratio

\begin{tabular}{|c|c|c|c|c|c|}
\hline \multirow{2}{*}{ NPL Ratio } & \multicolumn{5}{|c|}{ Number of Bank } \\
\cline { 2 - 6 } & 2009 & 2010 & 2011 & 2012 & 2013 \\
\hline $0-5 \%$ & 23 & 23 & 25 & 24 & 24 \\
\hline$>5 \%$ & 3 & 3 & 1 & 2 & 2 \\
\hline
\end{tabular}

Source: Data Processed, 2014

\subsection{Factors Affecting the NPL}

Based on the results of the Hausman test analysis shows that the most appropriate model to use is the Random Effect Model. Classical Assumption Test results showed that there was no violation, so it can be used multiple regression.

This approach uses the estimation process Generalized Least Square (GLS). Approach Random Effect Model (REM) is also called models Error Component Model (ECM). General regression model for NPL in BPD throughout Indonesia are as follows:

Yit $=0.6123-0.6652 \times 1+0.0571 \times 2+0.0746 \times 3+0.6521 \times 4+0.0830 \times 5$

Based on regression analysis can be explained that any increase in the ratio of $1 \%$ SIZE then NPL ratio will decrease by $0.6652 \%$, for every increase in CAR by $1 \%$ then the NPL ratio will increase by $0.0571 \%$, for every $1 \%$ increase in BOPO ratio of the NPL ratio will increased by $0.0746 \%$, for every increase of $1 \%$ ratio LIR the NPL ratio will increase by $0.6521 \%$, and for every increase of $1 \%$ LDR, the NPL ratio will increase by $0.0830 \%$.

\subsection{Simultaneous Significance Test (Test F Statistics)}

Simultaneous significance test ( $F$ test statistic) aimed to show whether all the independent variables used simultaneously influence on the dependent variable or not.

Here are the results of simultaneous significance test ( $F$ test statistic) is shown in Table 2, with hypothesis testing as follows:

$\mathrm{HO}: \beta 1=\beta 2=\beta 3=\beta 4=\beta 5=0 \quad$ (the model is not significant)

H1: minimal satu tidak sama dengan nol (the model is significant)

a: $5 \%$ 
Test criteria: $\mathrm{H} 1$ is accepted if the $\mathrm{p}$-value $\leq \mathrm{a}$.

Table 2. Results of Test Statistic F

\begin{tabular}{|c|c|c|}
\hline Test Statistic F & P-Value & Conclusion \\
\hline 7.5184 & $1 \mathrm{e}-13$ & $\mathrm{H}_{1}$ received \\
\hline
\end{tabular}

Source: Data Processed, 2014

Based on the calculations, the $p$-value $=1 \mathrm{e}-13$ is smaller than the value of $\alpha=5 \%$ so that $\mathrm{H} 1$ is accepted which means that the regression model is significant. It shows that simultaneously measure banks, CAR, BOPO, LDR and LIR has an influence on the NPL.

\subsection{Parsial Significance Test (Test $t$ Statistics)}

The purpose of partial significance test (t test statistic) is to determine whether each independent variable (SIZE, CAR, BOPO, LIR and LDR) affect the dependent variable (NPL) is significant or not. Here are the results of the partial significance test (t test statistic) is shown in Table 3

Table 3. Results of Test Statistic t

\begin{tabular}{|c|c|c|c|}
\hline Variable & Estimationi & P-Value & Conclusion \\
\hline SIZE & -0.6652 & 0.30932 & not significant \\
\hline CAR & 0.0571 & 0.05507 & not significant \\
\hline BOPO & 0.0746 & 0.00155 & significant \\
\hline LIR & 0.0830 & 0.00321 & significant \\
\hline LDR & 0.6521 & 0.00089 & significant \\
\hline
\end{tabular}

\section{Source: Data Processed, 2014}

Based on the results of the $t$ test above can be seen that the variable BOPO, LIR and LDR which has a $p$-value less than $\alpha=0.05$, mean BOPO, LIR and LDR significant effect on the NPL. Whereas other variables such as SIZE and CAR that has a p-value greater than $\alpha=0.05$ means no significant effect on the NPL.

The test results explained that the variable BOPO, LIR and LDR which have a significant impact on the level of NPL. In other words, the variable BOPO which reflects the level of efficiency of the bank becomes an important factor to be watched because of proven effect on the level of NPL in the bank BPD. Then the bank liquidity variable (LDR) and the loan interest rate also determines to NPL. As for the other variables, namely SIZE and CAR does not have a significant impact on the level of NPL.

SIZE variable is the log of the total assets of the results showed that the level of bank size judged by a large assets. SIZE variable yield negative sign of the coefficient estimates. This reflects the greater the level of bank size (SIZE) reflects the level of quality to better management in the analysis and evaluation of the credit agreement and allow greater diversification opportunities, so as to reduce the level of NPL.

Results of partial significance test (t test statistics) indicates that the variable SIZE does not have a significant impact on banks NPL variable BPD. These results indicate that the size of the banks (SIZE) not including the deciding factor in changes in the level of NPL, although the larger banks have quality resources and a better ability in the selection and diversification of credit, but the level of NPL can be comparable to total loans where large banks tend to have high levels of lending (LDR) high.

Other factors can also be caused due to the risk of this type of use of credit issued by a bank, such as lending to the agricultural sector which has a huge business risk and unpredictable. For example in agricultural credit, times of crop failure caused by natural disasters, pests or other disaster, the credit risks can not be avoided even by the managerial ability of banks. This could be an explanation why SIZE variable does not affect the banks NPL variable BPD.

This result is different from that performed by Ranjan and Dahl (2003), Syeda Zabeen Ahmed (2006), BM Misra and Dahl (2010) and Km. Suli Astrini, I Wayan Suwendra and I Ketut (2014) that can affect the size of the bank's NPL According to the study larger banks are better able to control the non-performing loans by relying on diversified credit 
portfolio. Diversification is done to focus lending by sector so that more specific. With the diversification of the loan, the process of selecting and monitoring credit can be more focused and better, it can minimize the risk of credit or NPL.

CAR variable yield partial significance test (t test statistic) no significant effect on the NPL. This means that whatever CAR owned by a bank will not affect the NPL. CAR are getting bigger means the owners of the bank to raise capital. However, the capital increase by the management are used for other investments, not to increase the allocation of outstanding loans or cover to cover credit risk has occurred.

The results of this study different from those of Das and Ghosh (2007), Poetry and Sanrego (2011), as well as Vatansever \& Hepsen (2013) that the CAR effect on the NPL. When CAR increases, meaning capital reserves owned banks also increased and can be used to cover the credit risk that has occurred.

BOPO variable yield coefficient estimates are negative sign, which means the higher the BOPO ratio of NPL banks will increase. Variables BOPO is calculated by using the ratio of operating expenses to operating income indicate that the value of the higher BOPO ratio indicates the level of the lower bank efficiency (inefficient). In contrast, the value of the lower BOPO ratio indicates the level of bank efficiency, the better.

The results of partial significance test (t test statistics) indicates that the variable BOPO significant effect on the $\mathrm{NPL}$, meaning BOPO variables that reflect the level of bank efficiency proved influential in changing the level of NPL banks BPD. The level of bank efficiency can reflect the level of quality management and the effectiveness of the services that run products are applied by the bank. Inefficiency banks often caused by poor quality of management so that the supervision and control of the use is not done properly. The low quality of management also resulted in poor credit management process that contributes to the high level of NPL. Banks that have good efficiency with low BOPO ratio, indicating that the bank has a good quality of human resources in managing the operations of a bank and a good ability to credit approval. So the more efficient banks in their efforts to suppress the occurrence of a credit risk, because the credit disbursed through the process of selection was good.

The results are consistent with research conducted Berger and De Young (1997), Karim \& Hassan (2010) and Vatansever \& Hepsen (2013). The results of the research shows that a bank with an efficiency rate lower cost (BOPO increases) will increase non-performing loans. Inefficient banks have bad management in managing their credit risk and it leads to increase non-performing loans or NPL.

Results of partial significance test (t test statistics) indicates that the variable interest rate loans (LIR) has a significant effect on the NPL banks BPD. Lending rates are not only based on the concept of cost of funds, but also much influenced by other factors, such as the number of requests that apply for credit, competitors, and development policy implementation fixed or floating interest rates. Thus, the determination of lending rates are higher in banks BPD addition to these factors is also intended for the profit margins of banks as well as to cover the risks that will happen. Banks BPD during the many high-risk lending, so the interest rate demanded by the bank loan is also higher. This is in accordance with the said Sutoyo (2000) the higher level of credit risk the higher the interest rate the bank requested. The high interest rates that led to a debtor is experiencing difficulties in mortgage payments.

The results are consistent with what is done Hermawan Subagyo (2005) and BM Misra and Loaded Dahl (2010) that the loan interest rate can affect the credit crunch. Although different loci and research time, can be understood logically that the high interest rate loans lenders will feel the burden of the debtor usually remains in the form of a higher interest rate. However, the results of this study differs from that carried Aisha and Prasetya (2012) that the loan interest rate has no effect on the NPL.

Results of partial significance test (t test statistics) show that bank liquidity variable (LDR) has a significant influence on banks NPL variable BPD. Higher LDR values indicate banks lending BPD in doing is increasing. Incessant lending conducted in accordance with the target BPD who wants to become a national scale bank. Credit disbursement BPD often not only in the province, but extends to other provinces. BPD extend credit to sectors of high-risk businesses such as mining and plantations. However, because of BPD is not ready to manage the risk that credit management is not maximized, so that the credit problems will also increase.

The results are consistent with what is done BM Misra and Loaded Dahl (2010) that an increase in the LDR will be followed by an increase in non-performing loans. The same study conducted Novitayanti and Baskara (2012) who said that the decline in LDR significant effect on the NPL.

\section{Conclusion}

Based on the results obtained the following conclusions:

a. The size of banks, capital adequacy ratio, and the efficiency of the bank, loan interest rate, and liquidity of banks simultaneously can affect the credit crunch. 
b. Partially, which can affect the efficiency of problem loans made by banks, mortgage interest rate and liquidity of banks. While the size of the banks and the capital adequacy ratio of the partial does not affect nonperforming loans

\section{References}

Ahmed, Zabeen, Syeda (2006). An Investigation of The Relationship Between Non-Performing Loans, Macroeconomic Factors, and Financial Factors in Context of Private Commercial Banks in Bangladesh. An Internship Report Presented in Partial Fulfillment of the Requirements for the Degree Bachelor of Business Administration Independent University, Bangladesh.

Berger, Allen N, and DeYoung, Robert, 1997. Problem Loan and Cost Effeciency in Commercial Banks, Forteoming, Journal of Banking and Finance, Vol.21

Das, A., \& Ghosh, S. 2007. Determinants of Credit Risk in Indian State-owned Banks: An Empirical Investigation. Economic Issues Vol.12 Issue 2, 27- 46.

Dendawijaya, Lukman. 2003. Manajemen Perbankan, Edisi Kedua. Jakarta: Ghalia Indonesia.

Hermawan Subagyo, 2005. Analisis Faktor-faktor yang Mempengaruhi Terjadinya Non Performing Loan (NPL) pada Bank Umum Komersil, Tesis, Program Pascasarjana Universitas Dipenogoro.

Inas Aisha dan Ferry Prasetya. 2012. Keterkaitan Variabel Makroekonomi Regional dengan Risiko Kredit, JIMFEB Universitas Brawijaya Vol. 1 No. 2.

Kasmir. 2008. Dasar-Dasar Perbankan. Jakarta: Raja Grafindo Persada.

Km.Suli Astrini, I Wayan Suwendra, dan I Ketut Suwarna. 2014. Pengaruh CAR, LDR, Dan Bank Size TERHADAP , e-Journal Bisma Universitas Pendidikan Ganesha Jurusan Manajemen.

Koch, Timothy W and S. Scott MacDonald, 2003. Bank Management, 5th Edition. United State : Navta Associates, Inc.

Latumaerissa, Julius R, 1999. Mengenal Aspek-Aspek Operasi Bank Umum, Bumi Aksara, Jakarta.

Martono dan D Agus Harjito. 2008. Manajemen Keuangan. cetakan ketujuh. Yogyakarta: Ekonisia

Mishkin, Frederic S. 2001. The Economics of Money, Banking, and Financial Market (6th edition). New York.

Misra, B.M and Dhal, Sarat. 2010. Pro-cyclical Management of Banks' Non-Performing Loans by the Indian Public Sector Banks. BIS Asian Research Papers, June, 2010

Malayu Hasibuan, 2006. Dasar-Dasar Perbankan, Jakarta: Bumi Aksara.

Mohd Zain Abd Karim, Sok-Gee Chan, Sallahudin Hassan (2010), " Bank Efficiency and Nonperforming Loans: Evidence from Malaysia and Singapore, http://www.researchgate.net/publication/46560594_Bank_Efficiency_And_Non-Performing_Loans_Evidence_ From_Malaysia_And_Singapore

Novitayanti, Angga dan Baskara, Kajeng. 2012. Analisis Kebijakan Perkreditan dan Pengaruh LDR Terhadap NPL pada Bank Sinar. Jurnal Akuntansi Fakultas Ekonomi Universitas Udayana

Rahmat Firdaus, Maya Ariyanti, 2003. Manajemen Perkreditan Bank Umum. Teori, Masalah, Kebijakan dan Aplikasinya Lengkap dengan Analisis Kredit, Alfabeta, Bandung.

Ranjan, R. \& Dhal, S.C. 2003. Non-Performing Loans and Terms of Credit of Public Sector Banks in India: An Empirical Assessmen. Reserve Bank of India Occational Papers Vol. 24 No. 3.

Rivai. Veithzal. 2006. Credit Management Handbook:Teori, Konsep, dan Aplikasi Panduan Praktis Mahasiswa, Bankir dan Nasabah. Jakarta: Raja Grafindo Persada.

Riyadi, Selamet. 2006. Banking Assets and Liability Management (Edisi Ketiga). Jakarta: Lembaga Penerbit FEUI.

Siamat, Dahlan. 2005. Manajemen Lembaga Keuangan. Kebijakan Moneter dan Perbankan, Edisi Kesatu. Jakarta: FEUI.

Suta, I Putu Gede Ary \& Musa, Soebowo. 2003. Membedah Krisis Perbankan. Jakarta: Yayasan SAD Satria Bhakti.

Taswan. 2006. Manajemen Perbankan. Yogyakarta : UPP STIM YKPN

Teguh Pudjo Muljono. (2007). Manajemen Perkreditan Bagi Bank Komersiil. Edisi 4. Yogyakarta : BPFE

Vatansever, M. \& Hepsen, A. 2013. Determining Impacts on Non-Performing Loan Ratio in Turkey. Journal of Finance and Investment Analysis.

Zakiyah Dwi Poetry, Yulizar D Sanrego. 2011. Pengaruh Variabel Makro dan Mikro Terhadap NPL Perbankan Konvensional dan NPF Perbankan Syariah. Islamic Finance \& Business Review Vol. 6 No.2 Agustus - Desember 